\title{
Lembar Kerja Peserta Didik Berbasis Model Integrated di Sekolah Dasar
}

\author{
Fetra Bonita Sari ${ }^{1}$, Risda Amini ${ }^{2}$, Mudjiran ${ }^{3}$ \\ Pendidikan Dasar, Universitas Negeri Padang, Sumatera Barat, Indonesia ${ }^{1}$ \\ Pendidikan Dasar,Universitas Negeri Padang, Sumatera Barat, Indonesia ${ }^{2,3}$ \\ E-mail: fetra_bonita@yahoo.co.id ${ }^{1}$ risdamini@yahoo.co.id ${ }^{2}$ mudjiran.unp@gmail.com ${ }^{3}$
}

\begin{abstract}
Abstrak
Penelitian ini bertujuan untuk menghasilkan lembar kerja peserta didik mengunakan model integrated, yang valid, praktis, dan efektif, pada kelas IV SD. Penelitian pengembangan ini mengacu pada model 4D, dengan tahap tahap pendefinisian (define), perancangan (design), pengembangan (development), dan penyebaran (disseminate). LKPD yang dikembangkan divalidasi oleh ahli dibidang isi, konstruk, bahasa,dan kegrafikan. Kemudian LKPD tematik terpadu diujicobakan untuk melihat kepraktisan dan keefektifan dari LKPD tematik terpadu tersebut. Kepraktisan LKPD dilihat dari angket respon guru dan siswa, keefektifan dilihat dari observasi aktivitas dan hasil belajar siswa. Hasil penelitian diperoleh, nilai validasi LKPD rata-rata 3,6 dengan kategori sangat valid. Pada tahap praktikalitas, diperoleh hasil bahwa LKPD sudah praktis. Ketuntasan hasil belajar siswa mencapai $83 \%$ kategori tuntas. Dari hasil penelitian diperoleh bahwa LKPD yang dikembangkan telah valid, praktis dan efektif digunakan di kelas IV sekolah dasar.
\end{abstract}

Kata kunci: LKPD, model integrated, sekolah dasar

\section{Abstract}

This study aims to produce student worksheets using an integrated model, which is valid, practical, and effective, in grade IV SD. This development research refers to the 4-D model, with the stages of defining, designing, developing and disseminating. The developed LKPD is validated by experts in the fields of content, constructs, language, and graphics. The integrated of thematic LKPD was tried out to see the practicality and effectiveness of the integrated thematic LKPD. The practicality of the LKPD is seen from the questionnaire responses of teachers and students, the effectiveness is seen from the observation of activities and student learning outcomes. The results obtained, the average LKPD validation value was 3.6 with a very valid category. At the practicality stage, the results show that LKPD is practical. The completeness of student learning outcomes reached $83 \%$ complete category. From the research results, it was found that the developed LKPD was valid, practical and effective in use in grade IV elementary schools.

Keywords: LKPD, integrated model, elementary school

Copyright (c) 2020 Fetra Bonita Sari, Risda Amini, Mudjiran

$\triangle$ Corresponding author

Address : Air Tawar Padang

Email : fetra_bonita@yahoo.co.id

Phone : 089531307164

ISSN 2580-3735 (Media Cetak)

ISSN 2580-1147 (Media Online)

DOI: https://doi.org/10.31004/basicedu.v4i4.524 
1195 Lembar Kerja Peserta Didik Berbasis Model Integrated di Sekolah Dasar - Fetra Bonita Sari, Risda Amini, Mudjiran

DOI: https://doi.org/10.31004/basicedu.v4i4.524

\section{PENDAHULUAN}

Kurikulum

2013

menggunakan

pembelajaran tematik, pembelajaran tematik dikatakan bermakna bagi siswa karena dalam pelaksanaannya, siswa akan memahami konsepkonsep yang mereka pelajari melalui pengalaman langsung dan menghubungkannya dengan konsep lain yang telah mereka pahami sebelumnya (Bentri, Adree, \& Putra, 2014). Terkait dengan hal tersebut, proses pembelajaran akan lebih dipahami siswa secara mendalam jika mereka sendiri yang terlibat aktif dalam pembelajaran tersebut. Seperti hakikat pembelajaran yang sebenarnya yakni pembelajaran adalah prosedur dan metode yang ditempuh oleh pengajar untuk memberikan kemudahan bagi peserta didik untuk melakukan kegiatan belajar secara aktif dalam mencapai tujuan pembelajaran (Kemendikbud, 2013).

Muslich (2008) menyatakan bahwa belajar dengan menggunakan banyak indera akan lebih tahan lama dalam ingatan siswa dari pada hanya mendengarkan orang lain atau mendengar penjelasan guru (Muslich, 2008). Pemahaman yang diperoleh siswa hanya dari penjelasan lisan guru jauh lebih mudah terlupakan dari pada pemahaman yang mereka bangun sendiri dari pengalaman atau kegiatan-kegiatan yang dilakukan dalam proses pembelajaran (Amini, Setiawan, Fitria, \& Ningsih, 2019). Oleh karena itu, guru seharusnya menciptakan suasana pembelajaran yang dapat melatih siswa untuk mengeksplorasi dan membangun pemahamannya sendiri yaitu siswa belajar dengan melakukan kegiatankegiatan, bukan dengan terus "disuapi" yakni hanya duduk mendengarkan penjelasan dari guru (Nur Utami \& Mustadi, 2017).

Upaya guru untuk menciptakan suasana pembelajaran tersebut, tentunya harus didukung dengan perangkat-perangkat pembelajaran yang disusun oleh guru itu sendiri. Berdasarkan hal tersebut, maka perlu diadakannya pengembangan perangkat pembelajaran yang dirancang untuk lebih mengaktifkan siswa dalam kegiatan proses pembelajaran (Usmeldi, Amini, \& Trisna, 2017). Maka dari itu, penulis bermaksud untuk mengembangkan Lembar Kerja Peserta Didik (LKPD) untuk kelas IV sekolah dasar pada pembelajaran tematik subtema sumber energi (Sudrajat \& Surbakti, 2017).

LKPD merupakan lembaran yang berisi pedoman bagi siswa untuk melakukan kegiatan yang terprogram dalam proses pembelajaran. LKPD adalah lembar kerja yang berisikan informasi dan interaksi dari guru kepada siswa agar dapat mengerjakan sendiri suatu aktifitas belajar, melalui praktek atau penerapan hasil-hasil belajar untuk mencapai tujuan intruksional (Nurmalena, 2017). LKPD memiliki peranan yang sangat penting dalam proses pembelajaran terutama dalam pembelajaran student centered karena dengan digunakannya LKPD dapat meningkatkan aktivitas siswa dalam belajar dan membantu guru dalam mengarahkan siswa menemukan konsep melalui aktivitas secara mandiri (Ruzadiana \& Ertikanto, 2018). Selain itu, LKPD yang berkualitas baik harus memenuhi syarat-syarat tertentu, yakni : (a) syarat didaktik, (b) syarat konstruksi, dan (c) syarat teknis. 
1196 Lembar Kerja Peserta Didik Berbasis Model Integrated di Sekolah Dasar - Fetra Bonita Sari, Risda Amini, Mudjiran

DOI: https://doi.org/10.31004/basicedu.v4i4.524

Realitas pendidikan dilapangan kita lihat banyak pendidik yang masih menggunakan bahwa LKPD yang dibuat oleh guru masih dalam bentuk permuatan pelajaran (Waluyo, Sa'dijah, \& Subanji, 2016). Artinya, dalam pembuatan LKPD guru memisahkan masing-masing muatan pelajaran. Hal ini tidak relevan dengan pembelajaran tematik terpadu yang digunakan dalam kurikulum 2013, sehingga terdapat kesenjangan antara pembelajaran yang dilakukan dengan bahan ajar yang digunakan yakni LKPD. Selain itu, guru juga belum memahami pelaksanaan pembelajaran tentang kurikulum 2013 seutuhnya. Hal ini terlihat dari LKPD yang digunakan dalam pembelajaran seperti materi LKPD yang disajikan belum terpadu, LKPD yang digunakan tidak sesuai dan terkesan monoton karena belum dikembangkan, LKPD yang digunakan belum memberikan pembelajaran yang bermakna dan memberikan pengalaman belajar yang relevan (Usmeldi, 2016).

Mengatasi masalah tersebut guru hendaknya mampu mengembangkan lembar kerja yang akan diajarkan kepada peserta didik secara aktif dan kreatif dengan model pembelajaran yang tepat. Penggunaan lembar kerja yang dikembangkan seharusnya menggunakan model yang sesuai dengan tujuan pembelajaran yang ingin dicapai. Salah satu model pembelajaran yang dapat digunakan dalam pembelajaran tematik terpadu pada kurikulum 2013 adalah model integrated (Saputro, Marjuni, Kuswaya, Saputra, \& Fadly, 2019).

Model Integrated menjadikan materi pelajaran menjadi dekat dengan kehidupan anak sehingga anak dengan mudah memahami sekaligus melakukannya. Siswa juga dengan mudah dapat mengaitkan hubungan materi pelajaran di muatan pelajaran yang satu dengan muatan pelajaran lainnya (Amini \& Lena, 2019). Dengan bekerja dalam kelompok, siswa juga dapat mengembangkan kemampuan belajarnya dalam aspek afektif dan psikomotorik, selain aspek kognitif. Pembelajaran terpadu dapat memudahkan jenis aktifitas siswa. Dengan pendekatan pembelajaran terpadu guru dapat dengan mudah menggunakan belajar siswa aktif sebagai metode pembelajaran (Fogarty, 1991).

Hal-hal yang telah dipaparkan sebelumnya menjadikan latar belakang mengapa peneliti fokus pada prestasi belajar siswa SD menggunakan LKPD. Tujuan dari penelitian ini adalah menghasilkan LKPD menggunakan Model Integrated yang berkualitas valid, praktis dan efektif.

\section{METODE}

Jenis penelitian ini adalah penelitian pengembangan (devolepment research). Penelitian dilaksanakan di SDN 07 Ampang pada semester ganjil tahun pelajaran 2018-2019 bulan September 2018. Subjek penelitian adalah kelas IV SDN 07 Ampang.

Model pengembangan yang digunakan mengacu pada model 4D (Sugiyono, 2013). Model ini terdiri dari empat tahap yaitu 1) Pendefenisian (define) yaitu analisis tujuan dari batasan materi yang dikembangkan. 2) Perancangan (design) yaitu bertujuan untuk menyiapkan dan membuat Lembar Kerja Peserta Didik (LKPD) yang akan 
1197 Lembar Kerja Peserta Didik Berbasis Model Integrated di Sekolah Dasar - Fetra Bonita Sari, Risda Amini, Mudjiran

DOI: https://doi.org/10.31004/basicedu.v4i4.524

dikembangkan. 3) Pengembangan (develop) yaitu tahap validasi, revisi, dan uji coba. 4) Penyebaran (disseminate) yaitu untuk menguji efektivitas penggunaan Lembar Kerja Peserta Didik (LKPD) yang dikembangkan dalam proses pembelajaran.

Analisis data yang diperoleh dijabarkan sebagai berikut :1) Uji validitas Instrumen validasi meliputi lembar validasi Lembar Kerja Peserta Didik (LKPD) yang berisikan aspek-aspek penilaian yang meliputi kelayakan isi, kebahasaan, penyajian, dan kegrafikaan. 2) Uji Praktikalitas dari hasil pengamatan keterlaksanaan RPP menggunakan skala likert,angket respon guru dan angket respon siswa 3) Uji efektifitas LKPD dari hasil belajar dilihat standar KKM dan aktivitas siswa dengan menggunakan persentase.

\section{HASIL DAN PEMBAHASAN}

\section{Kevalidan}

Validitas dilakukan untuk menentukan kevalidan LKPD secara keseluruhan berdasarkan hasil penilaian validator. Hasil analisis validitas yang diperoleh secara keseluruhan disajikan pada Tabel 1.

Tabel 1. Rekapitulasi hasil validasi LKPD oleh pakar materi

\begin{tabular}{|l|l|c|l|}
\hline No & \multicolumn{1}{|c|}{$\begin{array}{c}\text { Aspek yang } \\
\text { dinilai }\end{array}$} & $\begin{array}{c}\text { Rata- } \\
\text { rata }\end{array}$ & Kriteria \\
\hline 1 & Kelayakkan Isi & 3,8 & Sangat valid \\
\hline 2 & Kebahasaan & 4 & Sangat valid \\
\hline 3 & Penyajian & 3.3 & Sangat valid \\
\hline 4 & Kegrafikaan & 3,25 & Sangat valid \\
\hline
\end{tabular}

Berdasarkan hasil penilaian validator, dapat disimpulkan LKPD dengan menggunakan Model Integreted dalam kategori sangat layak.
Secara keseluruhan, LKPD telah dinyatakan layak digunakan dalam pembelajaran IPA di SD kelas IV.

\section{Kepraktisan}

Kepraktisan LKPD yang dikembangkan dilihat dengan menyebarkan angket respon guru dan respon siswa serta diperkuat dengan wawancara secara langsung setelah pembelajaran selesai, hasil uji praktikalitas dapat diuraikan sebagai berikut :

\section{Tabel 1. Hasil Analisis Angket Respon Guru}

\begin{tabular}{|c|c|c|}
\hline No & Aspek yang Dinilai & $\begin{array}{l}\text { Rata } \\
\text {-rata }\end{array}$ \\
\hline 1. & $\begin{array}{l}\text { Bahasa yang digunakan pada LKPD } \\
\text { sesuai dengan EYD }\end{array}$ & 4 \\
\hline 2. & $\begin{array}{l}\text { Penempatan ilustrasi gambar yang tepat } \\
\text { sesuai dengan urutan materi }\end{array}$ & 4 \\
\hline 3. & $\begin{array}{l}\text { Penyajian kalimat mudah dipahami oleh } \\
\text { guru }\end{array}$ & 3 \\
\hline 4. & $\begin{array}{l}\text { LKPD memudahkan guru untuk } \\
\text { mengajarkan materi pada peserta didik. }\end{array}$ & 4 \\
\hline 5. & $\begin{array}{l}\text { Petunjuk pada LKPD memudahkan guru } \\
\text { untuk menyampaikan maksud dan tujuan } \\
\text { berbagai kegiatan kepada peserta didik }\end{array}$ & 3.5 \\
\hline 6. & $\begin{array}{llll}\text { LKPD memudahkan } & \text { guru untuk } \\
\text { menarik minat peserta } & \text { didik } & \text { dalam } \\
\text { pembelajaran } & & & \end{array}$ & 3.5 \\
\hline 7. & $\begin{array}{l}\text { Gambar dalam LKPD memudahkan } \\
\text { guru untuk membantu peserta didik } \\
\text { memahami materi }\end{array}$ & 4 \\
\hline 8. & $\begin{array}{l}\text { LKPD dapat dijadikan sebagai salah satu } \\
\text { sumber data untuk penilaian proses } \\
\text { pembelajaran }\end{array}$ & 3.5 \\
\hline & Jumlah & 29.5 \\
\hline & Rata-rata & 3.69 \\
\hline & Kategori & $\begin{array}{l}\text { Prakt } \\
\text { is }\end{array}$ \\
\hline
\end{tabular}

Tabel diatas menunjukkan bahwa persentase rata-rata penilaian responden terhadap LKPD berbasis Model Integrated berada pada 
1198 Lembar Kerja Peserta Didik Berbasis Model Integrated di Sekolah Dasar - Fetra Bonita Sari, Risda Amini, Mudjiran

DOI: https://doi.org/10.31004/basicedu.v4i4.524

kategori praktis yaitu 3,69. Ini artinya LKPD yang dikembangkan telah memiliki kepratisan baik dari penyajian maupun penggunaannya. Dengan demikian dapat disimpulkan bahwa kepraktisan LKPD berbasis Model Integrated berdasarkan angket respon guru dikategorikan praktis.

Tabel 2. Hasil Analisis Angket Respon Siswa

\begin{tabular}{|c|c|c|c|}
\hline \multirow[t]{2}{*}{ No } & \multirow[t]{2}{*}{ Pertanyaan } & \multicolumn{2}{|c|}{ Jawaban } \\
\hline & & $\begin{array}{c}\text { Respon } \\
\text { siswa }\end{array}$ & Kriteria \\
\hline 1. & $\begin{array}{l}\text { Tampilan } \\
\text { menarik }\end{array}$ & 3.60 & $\begin{array}{l}\text { Sangat } \\
\text { praktis }\end{array}$ \\
\hline 2. & $\begin{array}{l}\text { Bahasa LKPD mudah } \\
\text { dipahami }\end{array}$ & 3.79 & $\begin{array}{l}\text { Sangat } \\
\text { praktis }\end{array}$ \\
\hline 3. & $\begin{array}{l}\text { Tulisan, warna, dan } \\
\text { gambar LKPD menarik }\end{array}$ & 3.75 & $\begin{array}{l}\text { Sangat } \\
\text { praktis }\end{array}$ \\
\hline 4. & $\begin{array}{l}\text { Petunjuk LKPD mudah } \\
\text { pahami }\end{array}$ & 3.70 & $\begin{array}{l}\text { Sangat } \\
\text { praktis }\end{array}$ \\
\hline 5. & $\begin{array}{l}\text { LKPD menarik minat } \\
\text { belajar }\end{array}$ & 3.62 & $\begin{array}{l}\text { Sangat } \\
\text { praktis }\end{array}$ \\
\hline 6. & LKPD mudah dibaca & 3.70 & $\begin{array}{l}\text { Sangat } \\
\text { praktis }\end{array}$ \\
\hline 7. & $\begin{array}{l}\text { LKPD membuat aktif } \\
\text { belajar }\end{array}$ & 3.66 & $\begin{array}{l}\text { Sangat } \\
\text { praktis }\end{array}$ \\
\hline 8. & 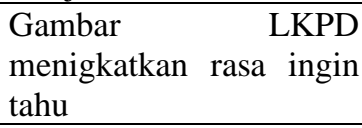 & 3.70 & $\begin{array}{l}\text { Sangat } \\
\text { praktis }\end{array}$ \\
\hline 9. & $\begin{array}{l}\text { LKPD meningkat minat } \\
\text { belajar }\end{array}$ & 3.54 & $\begin{array}{l}\text { Sangat } \\
\text { praktis }\end{array}$ \\
\hline 10. & $\begin{array}{l}\text { Materi LKPD mudah di } \\
\text { pahami }\end{array}$ & 3.66 & $\begin{array}{l}\text { Sangat } \\
\text { praktis }\end{array}$ \\
\hline & Rata-rata & 3.67 & $\begin{array}{l}\text { Sangat } \\
\text { praktis }\end{array}$ \\
\hline
\end{tabular}

Berdasarkan hasil analisis respon siswa dapat disimpulkan bahwa secara umum siswa merasa termotivasi dan terbantu dalam menemukan konsep selalu berhemat energi. LKPD yang digunakan sangat praktis untuk siswa hal terlihat dari rata-rata respon siswa 3,70 dengan katagori sangat praktis.

Keefektifan LKPD menggunakan Model Integreted yang dikembangkan dapat dilihat dari hasil proses pembelajaran peserta didik. Penilaian terdiri atas penilaian proses dan hasil belajar. Penilaian proses dilihat dari aktivitas peserta didik selama mengikuti pembelajaran dan tes hasil belajar. Aktivitas siswa selama kegiatan pembelajaran berlangsung diamati dengan menggunakan instrumen pengamatan aktivitas siswa. Hasil analisis aktivitas siswa secara keseluruhan disajikan pada uraian berikut ini.

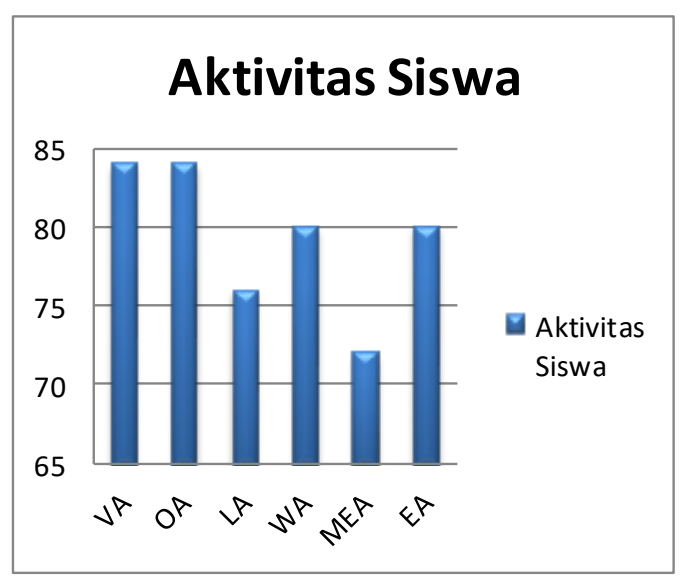

Grafik 1 .Hasil Pengamatan Aktivitas Siswa Kelas IV

Pada grafik di atas dilihat aktivitas siswa dalam kegiatan pembelajaran dengan menggunakan LKPD tematik terpadu berbasis Model Integrated di kelas IV SD berada dalam kategori Aktif. Hasil pengamatan aktivitas kegiatan pembelajaran menunjukkan bahwa aktivitas siswa selama melakukan kegiatan pembelajaran termasuk dalam kategori aktif, maka efektivitas LKPD tematik terpadu berbasis Model Integrated di kelas IV SD bisa dikatakan baik digunakan dalam kegiatan pembelajaran.

Tabel 3. Penilaian Hasil Belajar

\begin{tabular}{|l|l|l|l|}
\hline $\begin{array}{l}\text { Jumlah } \\
\text { Peserta }\end{array}$ & Jumlah & Rata- & Predikat \\
\hline
\end{tabular}




\begin{tabular}{|c|c|c|c|}
\hline Tes & Nilai & rata & \\
\hline 24 & 2040 & 85 & SB \\
\hline
\end{tabular}

Berdasarkan hasil belajar yang telah dicapai, maka terlihat bahwa pembelajaran dengan menggunakan LKPD dengan menggunakan Model Integrated tema 2 subtema 1 dapat membantu siswa meningkatkan aspek keterampilannya dengan rata-rata 85 dengan predikat sangat baik.

Produk penelitian yang telah dikembangkan dikatakan valid apabila memenuhi kriteria tertentu. Menurut Plomp (2010:127) karakteristik dari produk yang dikatakan valid apabila produk tersebut dapat merefleksikan jiwa pengetahuan (State of The Art Knowledge). Hal inilah yang dikatakan dengan validasi isi (content validity). Selanjutnya, komponen-komponen produk tersebut harus konsisten satu sama lain (validitas konstruk). Oleh sebab itu, validasi yang dilakukan terhadap produk penelitian ini menekankan pada isi dan konstruk.

\section{SIMPULAN}

Berdasarkan hasil penelitian dan pembahasan LKPD menggunakan Model Integreted yang dihasilkan pada penelitian pengembangan ini sangat valid. Selain itu kualitas LKPD menggunakan Model Integreted memenuhi kriteria sangat praktis dengan kategori baik. Hasil aktivitas dan prestasi belajar siswa terkategori baik sehingga LKPD menggunakan Model Integreted yang dikembangkan memenuhi kriteria efektif. Secara keseluruhan, LKPD menggunakan model integreted di SD kelas memenuhi kriteria valid, praktis dan efektif ditinjau dari LKPD dan prestasi belajar IPA siswa.

Adapun saran terkait dengan hasil dan temuan dalam penelitian ini adalah guru harus mampu membuat LKPD sendiri, terutama LKPD yang sesuai dengan karakterisitik siswa. Guru juga dapat menggunakan LKPD yang sudah ada, namun sebaiknya diperhatikan dulu kualitasnya dan kesesuaiannya dengan tujuan pembelajaran.

\section{DAFTAR PUSTAKA}

Amini, R., \& Lena, M. S. (2019). THE EFFECTIVENESS OF INTEGRATED LEARNING MODEL TO IMPROVE THE STUDENTS COMPETENCE AT ELEMENTARY SCHOOL. Unnes Science Education Journal, 8(1), 64-68. https://doi.org/http://dx.doi.org/10.15294/usej .v3i2.3349

Amini, R., Setiawan, B., Fitria, Y., \& Ningsih, Y. (2019). The difference of students learning outcomes using the project-based learning and problem-based learning model in terms of self-efficacy. In Journal of Physics: Conference Series. https://doi.org/10.1088/17426596/1387/1/012082

Bentri, A., Adree, O., \& Putra, A. (2014). Implementasi Kurikulum 2013 di Sumatera Barat. Jurnal Penelitian Pendidikan, 5(1), 88-99. https://doi.org/10.4324/9781315853178

Fogarty, R. (1991). Ten Ways to Integrate Curriculum. Educational Leadership.

Kemendikbud. (2013). Implementasi Kurikulum. Permendikbud. https://doi.org/10.1017/CBO9781107415324. 004

Muslich, M. (2008). KTSP Pembelajaran Berbasis Kompetensi Dan Kontekstual. Jakarta: PT. Bumi Aksara. https://doi.org/10.1016/j.sbspro.2014.09.352 
Nur Utami, K., \& Mustadi, A. (2017). Pengembangan Perangkat Pembelajaran Tematik Dalam Peningkatan Karakter, Motivasi, Dan Prestasi Belajar Siswa Sekolah Dasar. Jurnal Pendidikan Dan Pembelajaran, $\quad 7(1)$, 14-25. https://doi.org/10.21831/jpk.v7i1.15492

Nurmalena, D. (2017). Pengembangan LKPD Berbasis Inkuiri Terbimbing pada Pembelajaran IPS Kelas VI SDN Bumi Dana Kecamatan Way Tuba. Jurnal Pedagogi, 2(1).

Ruzadiana, L. M., \& Ertikanto, C. (2018). Pengembangan LKPD dengan Model PBL Sub Tema Macam-macam Sumber Energi Kelas IV SD. Jurnal Pendidikan IPA, (1), 115.

Saputro, B., Marjuni, K. N., Kuswaya, A., Saputra, H., \& Fadly, W. (2019). Developing stages for the scientific cues concept in the integrated science-tafseer learning model. Jurnal Pendidikan IPA Indonesia, 8(1), 6374. https://doi.org/10.15294/jpii.v8i1.17149

Sudrajat, A. A., \& Surbakti, A. (2017). Pengembangan LKPD Tematik Berbasis Problem Based Learning pada Materi Peninggalan-Peninggalan Kerajaan Islam di Indonesia untuk Kelas V SD.

Sugiyono. (2013). Metode Penelitian Pendidikan Pendekatan Kuantitaif, Kualitatif, dan R\&D. Metode Penelitian Pendidikan Pendekatan Kuantitaif, Kualitatif, Dan R\&D. https://doi.org/10.1007/s13398-014-0173-7.2

Usmeldi. (2016). The development of researchbased physics learning model with scientific approach to develop students' scientific processing skill. Jurnal Pendidikan IPA Indonesia, $\quad 5(1), \quad$ 134-139. https://doi.org/10.15294/jpii.v5i1.5802

Usmeldi, Amini, R., \& Trisna, S. (2017). The development of research-based learning model with science, environment, technology, and society approaches to improve critical thinking of students. Jurnal Pendidikan IPA Indonesia, 6(2), 318-325. https://doi.org/10.15294/jpii.v6i2.10680
Waluyo, E., Sa'dijah, C., \& Subanji. (2016). Pengembangan RPP dan LKPD Berbasis Realistic Mathematics Education dengan Memerhatikan Beban Kognitif Siswa Materi Bangun Ruang Sederhana Kelas IV SD. Jurnal Pendidikan: Teori, Penelitian, Dan Pengembangan, 1(12), 2300-2306. https://doi.org/10.17977/JP.V1I12.8248 